\title{
Effect of Different Salts on Mass Transfer Coefficient and Inorganic Fouling of TFC Membranes
}

\section{Gallab AAS ${ }^{1}$, Ali MEA ${ }^{1 *}$, Shawky HA ${ }^{1}$ and Abdel-Mottaleb MSA $^{2}$}

${ }^{1}$ Hydrogeochemistry department, Egyptian Desalination Research Center of excellence (EDRC), Desert Research Center,1 Mathaf El-Mataryia Street, 11753,Cairo, Egypt

${ }^{2}$ Nano-Photochemistry and Solar Chemistry Department, Faculty of Science, Ain Shams University, Abbaseyya, 11566, Cairo, Egypt

"Corresponding author: Mohamed EA Ali, Hydrogeochemistry department, Egyptian Desalination Research Center of excellence (EDRC), Desert Research Center, Mathaf El-Mataryia Street, 11753, Cairo, Egypt, Tel: (202) 27924 51; E-mail: m7983ali@gmail.com

Received date: August 3, 2017; Accepted date: August 22, 2017; Published date: August 26, 2017

Copyright: ๑ 2017 Gallab AAS, et al. This is an open-access article distributed under the terms of the Creative Commons Attribution License, which permits unrestricted use, distribution, and reproduction in any medium, provided the original author and source are credited.

\begin{abstract}
The behavior of reverse osmosis membranes against salts separation from salty water during desalination process depends mainly on ionic size, diffusivity and feed concentration of the solute. Here we studied the mechanism of different solutes transport through a commercial BW-TFC membrane using $\mathrm{NaCl}, \mathrm{CaCl}_{2}, \mathrm{Na}_{2} \mathrm{SO}_{4}$, and $\mathrm{MgSO}_{4}$ as feed solutions at different initial feed concentrations $(1000,2000,5000,10000 \mathrm{mg} / \mathrm{l})$ and two applied pressures (two and three folds of each salt osmotic pressure). In addition, the membrane transport parameters were investigated using two groundwater samples as feed solutions. The membrane transport parameters; solute transport parameter $\left(D_{A M} / K_{\delta}\right)$ and mass transfer coefficient $(k)$, useful for the prediction of the membrane performance, have been calculated by fitting the graphical method to the experimental results. To investigate effect of inorganic fouling onto the membrane performance, synthetic solutions (single solute) and two groundwater samples (multicomponent solute) have been used. Moreover, the membrane surfaces and their cross-sections were characterized using Scanning Electron Microscope to estimate the deposition and crystalline shape of salts onto the membrane surfaces. According to cross-flow results, it was found that calcium and magnesium salts fouled the membrane more than sodium salts, and the salt rejection percentage were in the order of $\mathrm{Na}_{2} \mathrm{SO}_{4}>\mathrm{NaCl}>\mathrm{MgSO}_{4}>$ $\mathrm{CaCl}_{2}$ in case of synthetic solutions and $\mathrm{CaSO}_{4}>\mathrm{MgSO}_{4}>\mathrm{MgCl}_{2}>\mathrm{Ca}\left(\mathrm{HCO}_{3}\right)_{2}>\mathrm{NaCl}$ in case of groundwater desalination.
\end{abstract}

Keywords Reverse osmosis membranes; Mass transfer coefficient; Solute transport parameter; Inorganic fouling

\section{Introduction}

Reverse osmosis (RO) technique is an important and rapidly growing source of providing drinking water and is widely used in desalination plants especially in remote areas because of its lower cost and simplicity $[1,2]$. Thin film composite (TFC) polyamide membranes is the most commercial type used in RO desalination plants. However, the water permeability and salt rejection of a membrane depends on its properties, solution chemistry, and operating conditions. Therefore, the membrane transport characteristics of any membrane kind should be studied to estimate the behavior of the membrane during desalination process. During $\mathrm{RO}$ desalination process, due to application of high pressure, the ions in solution are formed by the dissociation of inorganic salts in water and they are not free, they are surrounded by shells of water molecules i.e. hydrated ions, Figure 1. Despite many advantages of RO membranes, inorganic fouling using calcium and magnesium salts considers one of the serious problems facing the membranes because of scale formation onto the their surfaces, which lead to decline the water permeability, frequent cleaning and accelerates the membrane aging [3]. In that case, a solute concentration boundary layer at the liquid-membrane interface will be build-up, this layer known as concentration polarization (CP) that propagate the scale formation [4]. CP is the primary factor for the deviation of the permeate flux from being linear increasing with driving pressure [5]. During CP, the solute concentration at membrane surfaces could be greater than the concentration of bulk feed solution, which has a countering osmotic pressure beside the osmotic pressure of the bulk of solution [6]. Through desalination process, CP could be happen in two passes; from the membrane towards the bulk of feed solution that have the harmful effect, and from the membrane to the permeate side and this effect can be neglected [7]. Therefore, the solutes accumulation at the feed -membrane interface leads the solute molecules away from the membrane (i.e. solute back transfer). Due to the steady state, a phenomenon of equality the amount of solutes that pressed towards the membrane and that transferred back due to the boundary layer, would inversely affect the membranes life time. That phenomena leads to accumulation and stagnant of the ions at the boundary layer, consequently decreased the effective applied pressure because of the increasing retarding osmotic pressure resulting from $\mathrm{CP}$ boundary layer [7]. Consequently, RO membranes lifetime and permeate fluxes of the membrane are thought to be affected by the phenomena of CP formation (i.e., solute build-up) and fouling [8]. Concentration polarization depends on solute type, which is the most important factor affecting the membrane performance. For a better description of a $\mathrm{RO}$ system, and to predict the performance of $(\mathrm{RO})$ of desalination of natural groundwater applications it is essential to consider the mass-transfer both across the membrane and within a film layer. Many efforts have been made to determine the mass transfer coefficient, which is affected by CP $[9,10]$. Applying models to quantify the mass transfer coefficient is important to characterize the separation properties of the membrane that are characterized by certain parameters to describe the relative transport of solute and solvent through a membrane [11]. In the desalination process, it is essential to 
Page 2 of 9

determine the flow behaviour of the salt through membranes which is affected by some salt properties such as ionic size, diffusivity and concentration [12]. During the desalination process, as the water molecules pass through the membrane the concentration of salt near the membrane, at the feed side; will differ from the concentration at the bulk. The salt accumulation at the feed solution-membrane interface might lead to an equilibrium state under certain conditions [13]. At steady state the solute flux through the membrane is constant and equal to the solute flux throughout the film. The mass transfer coefficient $(\mathrm{k})$ helps understanding the behavior of each salt through its desalination [14]. The mass transfer coefficient is the amount of mass transport in a definite time through a semi permeable surface. There are many models that are used to determine the mass transfer coefficient in RO systems [15]. These models are divided into three types. The first type of models determining the mass transfer is the solution diffusion models and their modifications (e.g. homogeneous solution diffusion model), they assume that the membrane is membrane is a non-porous dense material and the solute react with the membrane material and diffuse through it and the RO process mechanism is a diffusion mechanism. The second type of these models are the size exclusion models (e.g. pore flow and film theory models)which assume that the membrane is a porous material which has channels or tunnels through which the solute particles pass and also assume that the desalination process happens through molecular sieving mechanism[16]. The third type of these models are the combination between the previously mentioned models (e.g. graphical method) and this type has the advantage of being simple equations, easier to operate and use and have less complicated terms. A previous work concluded that different models concerning the determination of mass transfer coefficient through RO membranes such as the, KimuraSourirajan Analysis (KSA) and the graphical method and in their work the equations of the solution-diffusion model and the film theory model are rearranged so that they can be used to estimate the membrane parameters; solute transport parameter $\left(D_{A M} / K_{\delta}\right)$ and the mass transfer coefficient $(\mathrm{k})$ simultaneously by a simple graphical method [17]. They also concluded that the KSA method is laborious and time consuming while the graphical model is suitable for estimation of the mass transfer coefficient especially when the salt rejection percentage is near or close to $100 \%$.

Based on literature reviews, the mass transfer coefficient is a function of feed flow rate, cell geometry and solute system. Here, only one of these parameters, solute type, was under investigation at constant feed flow rate. The membranes transport parameters were investigated using synthetic and natural groundwater samples. Where, the solutes that used were synthetic solution and groundwater during the RO desalination. The graphical model was used to estimate $\mathrm{D}_{\mathrm{AM}} /$ $\mathrm{K}_{\delta}$ and $\mathrm{k}$ values of four different salts of $\mathrm{NaCl}, \mathrm{CaCl}_{2}, \mathrm{Na}_{2} \mathrm{SO}_{4}$, and $\mathrm{MgSO}_{4}$ and two natural brackish and saline groundwater samples. In addition, Scanning Electron Microscope (SEM) images were interpreted to estimate the inorganic fouling onto the membrane surfaces as a result of scales and crystalline shape formation of different pressurized salts.

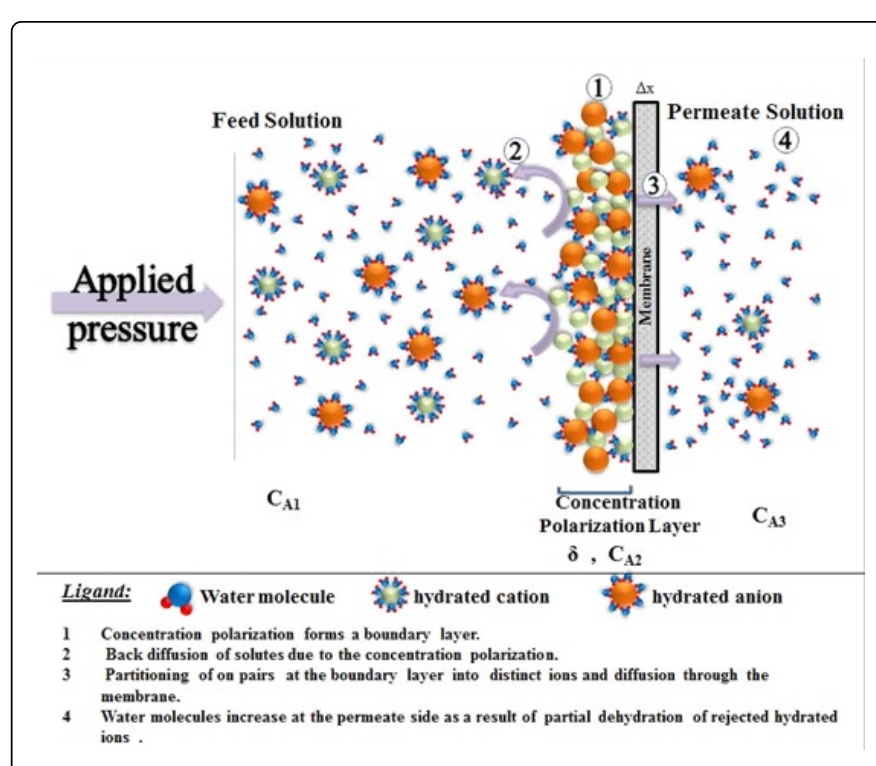

Figure 1: CP layer formation as a result of the RO filtration mechanism.

\section{Experimental Section}

\section{Materials}

Sodium Chloride (NaCl, M.W=58.44 g/mole) Sodium Sulphate anhydrous $\left(\mathrm{Na}_{2} \mathrm{SO}_{4}, \mathrm{M} . \mathrm{W}=142.036 \mathrm{~g} / \mathrm{mole}\right)$, Calcium Chloride dihydrate $\left(\mathrm{CaCl}_{2} \cdot 2 \mathrm{H}_{2} \mathrm{O}, \quad \mathrm{M} . \mathrm{W}=147.008 \mathrm{~g} / \mathrm{mole}\right)$, and Magnesium Sulphate hepta-hydrate $\left(\mathrm{MgSO}_{4} \cdot 7 \mathrm{H}_{2} \mathrm{O}, \mathrm{M} . \mathrm{W}=246.466 \mathrm{~g} / \mathrm{mole}\right)$ salts, commercial-grade chemicals were obtained from El-Gomhoreya Company for chemicals, Egypt. A commercial polyamide TFC flat sheet brackish water (BW) membrane (model: GE Osmonics Flat Sheet membrane, Thin Film RO SG, YMSGSP4205, Sterlitech) was used for reverse osmosis desalination process.

\section{Methods}

The membranes performance in terms of water flux $\left(\mathrm{J}_{\mathrm{v}}, \mathrm{L} / \mathrm{m}^{2} . \mathrm{h}\right)$ and salt rejection percent $\left(\mathrm{R}_{\mathrm{s}} \%\right)$ was determined using cross-flow test cell (model, Sterlitech ${ }^{\circ} \mathrm{CF} 042$ membrane test cell) with Hydra-cell pressure pump, with an active membrane surface area of $42 \mathrm{~cm}^{2}$. Figure 2 shows the schematic diagram of the cross-flow RO unit. For each experiment, the amount of permeate was collected initially after discarding permeate of the first hour, then all permeate amounts were collected each 30 minutes. Then the brine and permeate were returned to the feed container to maintain a continuous stream of a constant feed concentration. At the end of the $\mathrm{RO}$ operation, when the permeate conductivity reaches the steady state, permeate was collected from each of the three test cells and the conductivities were measured. The cross flow filtration system was allowed to run until the filtration operation conditions were stabilized. The feed flow rate was kept constant at $21 / \mathrm{min}$. 
Page 3 of 9

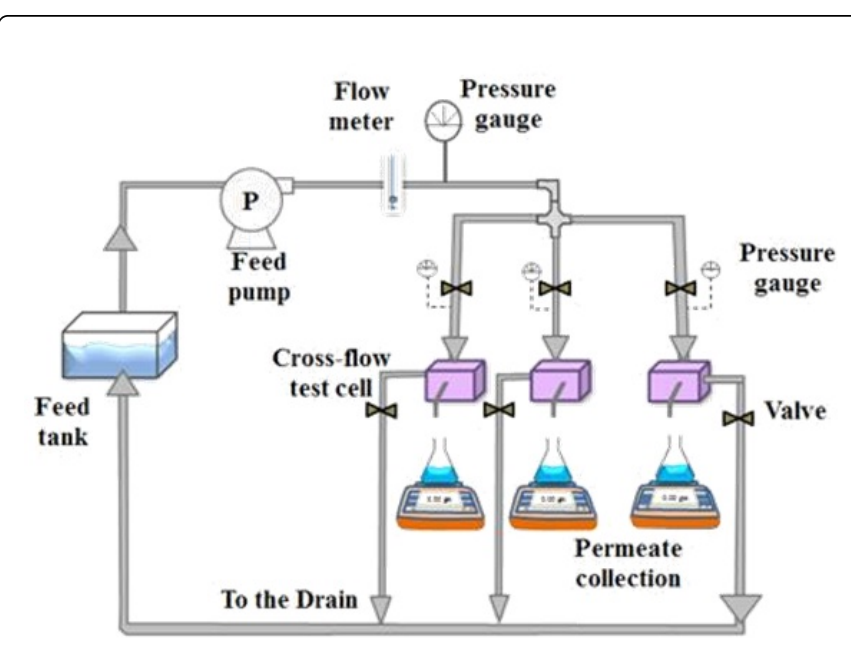

Figure 2: Schematic diagram of the cross-flow unit system.

The water flux $\left(\mathrm{J}_{\mathrm{v}}\right)$ expressed in weight of the product per unit membrane area during operation time in liter $\left(\mathrm{L} / \mathrm{m}^{2} . \mathrm{h}\right)$ was calculated as follow;

$$
J_{v}=\frac{Q}{A \times t}
$$

Where, $\mathrm{Q}$ is water permeates in liter, $\mathrm{A}$ is the membrane area in square meter and "t" is the time in hour. The equation of observed salt rejection $\left(\mathrm{R}_{\mathrm{s}} \%\right)$ calculation is:

$$
R_{s}=\left(\frac{{ }^{C_{f}-C_{p}}}{C_{f}}\right) \times 100
$$

Where $\mathrm{C}_{\mathrm{f}}$ and $\mathrm{C}_{\mathrm{p}}$ are the concentrations of feed and permeate water (product), respectively.

Pure water permeability (PWP) was determined by plotting the water flux vs. applied pressure $(2.5,5,10,15$ bar) using deionized water as a feed solution at $25^{\circ} \mathrm{C}$. The value of PWP was determined by applying Darcy's law (equation 10) of diffusion $[18,19]$ as follows;

$$
J_{v}=L_{p} \times \Delta P
$$

Where; Jw is the water flux, $\mathrm{P}$ is the applied pressure and LP is the permeability coefficient or hydraulic permeability.

The osmotic pressure $(\pi)$ of each salt was calculated from the following equation;

$$
\pi=i C R T
$$

Where, $i$ is the Van't Hoff's Factor, C is the molar concentration $(\mathrm{mol} / \mathrm{L}), \mathrm{R}$ is the universal gas constant $=0.082 \mathrm{~L} \cdot \mathrm{atm} \cdot \mathrm{K}^{-1} \cdot \mathrm{mol}^{-1}$ and $\mathrm{T}$ is the temperature in Kelvins. Table 1 shows the calculated osmotic pressure and estimated applied pressure values of different salts.

To calculate the membrane transport parameters and estimate the scale formation effect onto their performance, four different concentrations $(1000,2000,5000,10000 \mathrm{mg} / \mathrm{l})$ of $\mathrm{NaCl}, \mathrm{CaCl}_{2}, \mathrm{Na}_{2} \mathrm{SO}_{4}$ and $\mathrm{MgSO}_{4}$ were prepared by dissolving the predetermined amount of

\begin{tabular}{|c|c|c|c|c|}
\hline Pressure & $\mathrm{NaCl}$ & $\mathrm{Na}_{2} \mathrm{SO}_{4}$ & $\mathrm{CaCl}_{2}$ & $\mathrm{MgSO}_{4}$ \\
\hline Osmotic pressure & 1.7 & 1 & 1 & 0.5 \\
\hline Applied pressure $2 \pi$ & 3.5 & 2 & 2 & 1 \\
\hline Applied pressure $3 \pi$ & 5 & 3 & 3 & 1.5 \\
\hline
\end{tabular}
each salt in distilled water. Moreover, each concentration of a salt was pressurized at two and three folds of its osmotic pressure at a constant feed flow rate of $2 \mathrm{~L} / \mathrm{min}$.
Table 1: Osmotic and applied pressures of different salts at $2000 \mathrm{ppm}$.

The mass transfer coefficient $(\mathrm{k})$ and solute transport parameter $\left(D_{A M} / K_{\delta}\right)$ were determined from the resulted observed salt rejection and water fluxes and the results were fitted with the graphical method, in which $\mathrm{k}$ and $\mathrm{D}_{\mathrm{AM}} / \mathrm{K}_{\delta}$ were calculated from the slope $(1 / \mathrm{k})$ and the intercept, respectively. The following equation of combined solutiondiffusion and film theory models was used;

$$
\operatorname{Ln}\left[\left(1-R_{o}\right) /\left(J_{v} / R_{o}\right)\right]=\operatorname{Ln}\left[D_{A M} / K_{\delta}\right]+J_{v} / k
$$

Plotting Ln $\left[\left(1-R_{\mathrm{o}}\right) /\left(\mathrm{J}_{\mathrm{v}} / \mathrm{R}_{\mathrm{o}}\right)\right]$ vs. $\mathrm{J}_{\mathrm{v}}$, will yield a straight line with a slope $=1 / \mathrm{k}$ and an intercept of $\left(\mathrm{D}_{\mathrm{AM}} / \mathrm{K}_{\delta}\right)$.

Scanning Electron Microscope (SEM, QUANTA, FEG 250) was used to monitor the inorganic fouling onto the membrane surfaces. Where, five separate pieces of the same commercial membrane were used, one of them was considered as a control that was exposed to preconditioning with distilled water for 2 hours at 10 bars. Afterwards, each membrane was first preconditioned with distilled water for 2 hours, then exposed to desalination of a solution with $5000 \mathrm{mg} / \mathrm{l}$ from the following salts $\left(\mathrm{NaCl}, \mathrm{Na}_{2} \mathrm{SO}_{4}, \mathrm{CaCl}_{2}, \mathrm{MgSO}_{4}\right)$ for 12 hours at an applied pressure equals three folds of the osmotic pressure of each solution. Moreover, two groundwater samples with salinity of 5380 and $8540 \mathrm{mg} / \mathrm{l}$ were pressurized and SEM images were taken. SEM surface and cross-section images were taken and compared to the control membrane to indicate the inorganic fouling species and behavior.

\section{Results and Discussions}

The compaction of the used BW membrane as a function of the applied pressure was estimated through calculation the pure water permeability at different pressure. Figure 3 shows a non-linier proportion of the water flux against the applied pressure, indicating changes of the membrane's porosity and compaction of the membranes [19]. The figure shows that the slope was found to equal to $0.322 \mathrm{~L} /$ $\mathrm{m}^{2}$.h/bar, which is low to extent to the used membrane. After that, the solutes transport parameter through the membrane was investigated through measuring the salt rejection of four different salts $\left(\mathrm{Na}_{2} \mathrm{SO}_{4}\right.$, $\mathrm{NaCl}, \mathrm{MgSO}_{4}$ and $\mathrm{CaCl}_{2}$ ) at a constant concentration and different applied pressure based on the osmotic pressure of each salt. Figure 4 illustrates that the salt rejection was shown to be decreased in the following sequence; 97.9, 97, 93 and $92 \%$ for $\mathrm{Na}_{2} \mathrm{SO}_{4}, \mathrm{NaCl}, \mathrm{MgSO}_{4}$ and $\mathrm{CaCl}_{2}$, respectively. The unexpected increase of sodium salts rejection than divalent salts may be due to increasing of the applied pressure, which equals to triples of the salt osmotic pressure Table 1. In addition to the high diffusivity of $\mathrm{Mg}^{2+}$ and $\mathrm{Ca}^{2+}$ ions through the membrane, despite of their larger hydrated ionic radii Table 2. A little increase in the rejection of $\mathrm{Na}_{2} \mathrm{SO}_{4}$ than $\mathrm{NaCl}$ is due the difference in the counter ion size i.e. sulphate and chloride, where the sulphate anion is more bulky and larger hydrated radius compared to the chloride ion [20-22]. Meanwhile, the low rejection of $\mathrm{MgSO}_{4}$ is due to deterioration of the membrane surfaces because of high scale formation as a function of the inorganic fouling, which cause a reverse effect onto the membrane performance. A decreasing of $\mathrm{CaCl}_{2}$ 
Citation: Gallab AAS, Ali MEA, Shawky HA, Abdel-Mottaleb MSA (2017) Effect of Different Salts on Mass Transfer Coefficient and Inorganic

rejection percent was owing to the higher salt permeability of $\mathrm{Ca}^{2+}$ than sodium and magnesium ions [12].

\begin{tabular}{|l|l|l|l|l|}
\hline \multicolumn{1}{|c|}{ Ion } & $\begin{array}{c}\text { Diffusivity } \\
\left(10^{-9} \mathrm{~m}^{2} . \mathrm{sec}^{-1}\right.\end{array}$ & \multicolumn{1}{|c|}{$\begin{array}{c}\text { lonic radius } \\
(\mathrm{nm})\end{array}$} & $\begin{array}{c}\text { Hydrated } \\
\text { ionic } \\
\text { radius(nm) }\end{array}$ & $\begin{array}{c}\text { Hydration } \\
\text { energy } \\
\left(\mathrm{kJ}_{\mathrm{mol}}{ }^{-1}\right)\end{array}$ \\
\hline $\mathrm{Na}+$ & 1.333 & 0.095 & 0.365 & 407 \\
\hline $\mathrm{Mg}++$ & 0.706 & 0.074 & 0.429 & 1921 \\
\hline $\mathrm{Ca} 2+$ & 0.92 & 0.099 & 0.349 & 1584 \\
\hline $\mathrm{Cl}-$ & 2.032 & 0.181 & 0.347 & 376 \\
\hline $\mathrm{HCO3-}$ & 1.85 & -- & -- & -- \\
\hline $\mathrm{SO} 42-$ & 1.065 & 0.23 & 0.38 & 1138 \\
\hline
\end{tabular}

Table 2: Diffusivities, ionic radius and hydration energy of the studied ions.

Figure $5 \mathrm{a}$ and $5 \mathrm{~b}$ shows the effect of feed concentration of different salts on the solute transport parameter $\mathrm{D}_{\mathrm{AM}} / \mathrm{K}_{\delta}$ and mass transfer coefficient $(\mathrm{k})$, respectively, at a constant feed flow rate. It was found that the two parameters values were gradually increased as a function of feed solution salinity increases with all salts, except calcium chloride that shows a reverse relation. In addition, the effect of applied pressure and feed concentration on the mass transfer coefficient was investigated Table 3. From the table, it was observed that both of the applied pressure and feed concentration have a great effect on the mass transfer coefficient, where it values for the calcium \& magnesium salts were higher than that of sodium salts, the matter which indicated the higher diffusivity of these ions, subsequently their lower rejection. The lower of water flux in case of calcium salt than that of sodium salts indicating a scaling occurrence which is responsible for the flux decline. The increasing of $\mathrm{k}$ values in case of calcium chloride at low pressure (twice the osmotic pressure) is due to lowering CP effect at the membrane boundary layer, which enhances the ions transport through it. As the feed concentration increases up to 5000 and 10000 $\mathrm{mg} / \mathrm{l}, \mathrm{CP}$ plays an important role in blocking the pores of the membrane and hindered further passage of ions. When applying the high pressure (three folds of the osmotic pressure) on the calcium salt as feed solution, CP layer is formed quickly and further passage of ions is hence low and nearly constant through the membrane. For sodium salts of low diffusivity, the rapidly increases of mass transfer coefficient at low pressure (twice the osmotic pressure) was due to the small scale build-up formation onto the membrane surface, which increases gradually with increasing the feed concentration as CP layer increase. With increases of the applied pressure to be three folds of the osmotic pressure, the $\mathrm{CP}$ effect appear at high concentration, preventing further salt passage that results in decreasing the mass transfer coefficient [23].

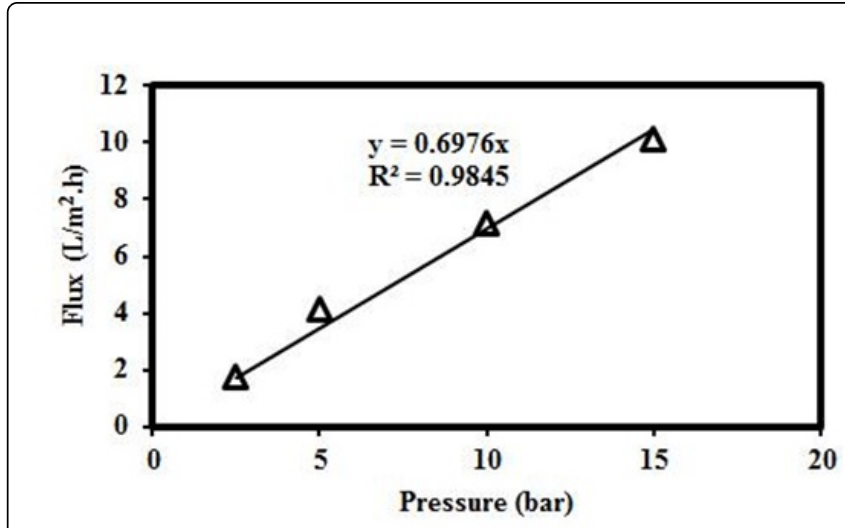

Figure 3: Water flux variation as a function of applied pressure.

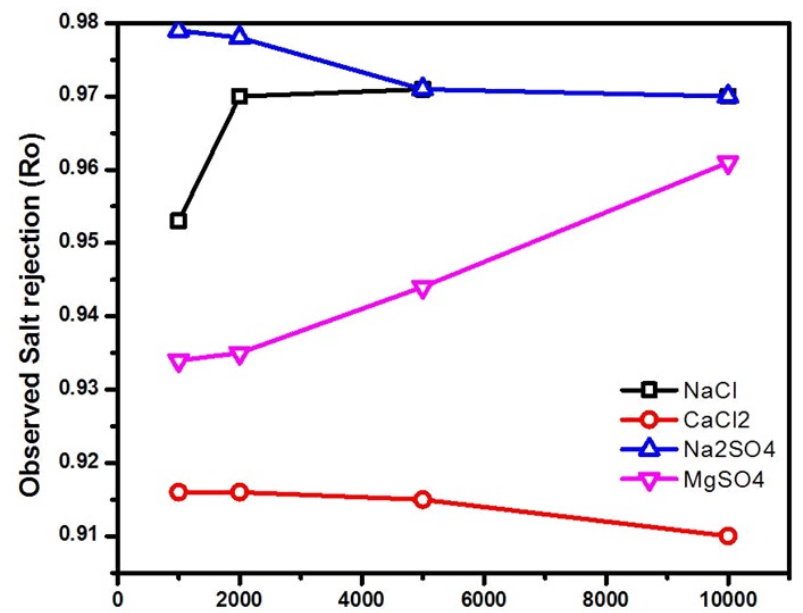

Figure 4: Variation of salt rejection of each salt as a function of solute concentration. 
Citation: Gallab AAS, Ali MEA, Shawky HA, Abdel-Mottaleb MSA (2017) Effect of Different Salts on Mass Transfer Coefficient and Inorganic

Page 5 of 9
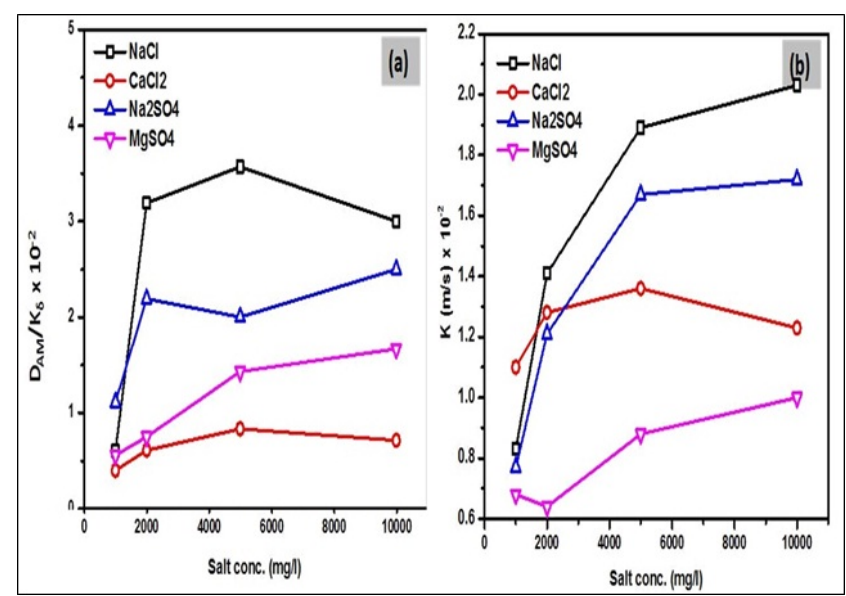

Figure 5: Effect of solute concentration onto membrane transport parameters, a) solute transport parameter and b) Mass transfer coefficient.
To investigate the membrane transport parameters and inorganic fouling in case of multi-ionic system, two groundwater samples with salinities of 5380 and $8540 \mathrm{mg} / \mathrm{l}$ were selected. Hypothetically, the combination between major anions and cations in groundwater lead to formation of salts. However, the relations between cations and anions in the investigated waters are illustrated in the form of bar graphs [24], Figure 6 The calculated hypothesized salts of two samples were found to be $\mathrm{NaCl}, \mathrm{MgCl}_{2}, \mathrm{MgSO}_{4}, \mathrm{CaSO}_{4}$ and $\mathrm{Ca}\left(\mathrm{HCO}_{3}\right)_{2}$. Figure 7 shows $\mathrm{Rs}$ $\%$ of the calculated hypothetical salts at different applied pressures, where the salt rejection was observed to be decreased in the following order; $\mathrm{CaSO}_{4}>\mathrm{MgSO}_{4}>\mathrm{MgCl}_{2}>\mathrm{Ca}\left(\mathrm{HCO}_{3}\right)_{2}>\mathrm{NaCl}$. Where, the membrane has shown high rejection for calcium and magnesium salts and low rejection for $\mathrm{NaCl}$ salt.

\begin{tabular}{|c|c|c|c|c|c|c|c|}
\hline \multirow{2}{*}{ Salt } & \multirow{2}{*}{$\begin{array}{l}\text { Feed } \\
\text { Concentration (mg/l) }\end{array}$} & \multicolumn{3}{|c|}{ Pressure $=2 \pi$} & \multicolumn{3}{|c|}{ Pressure $=3 \pi$} \\
\hline & & $J_{V}\left(L / m^{2} \cdot h r\right)$ & $\mathrm{R}_{0} \%$ & $\mathrm{~K}(\mathrm{~m} / \mathrm{s}) \times 10^{-2}$ & $J_{V}\left(L / m^{2} \cdot h r\right)$ & $\mathrm{R}_{0} \%$ & $\mathrm{~K}(\mathrm{~m} / \mathrm{s}) \times 10^{-2}$ \\
\hline \multirow{4}{*}{$\mathrm{NaCl}$} & 1000 & 2.08 & 94.1 & 0.83 & 2.4 & 95.4 & 1.53 \\
\hline & 2000 & 4.67 & 96.9 & 1.41 & 5.1 & 97 & 2.33 \\
\hline & 5000 & 3.3 & 97 & 1.89 & 9.3 & 97 & 1.23 \\
\hline & 10000 & 10.03 & 97.2 & 2.03 & 9.4 & 97.7 & 1.02 \\
\hline \multirow{4}{*}{$\mathrm{Na} 2 \mathrm{SO} 4$} & 1000 & 2.64 & 97.8 & 0.77 & 2.7 & 98 & 0.14 \\
\hline & 2000 & 1.77 & 96.3 & 1.21 & 2.8 & 97.9 & 0.75 \\
\hline & 5000 & 2.94 & 95.8 & 1.67 & 4.2 & 97.1 & 1.28 \\
\hline & 10000 & 4.88 & 95.4 & 1.72 & 7.9 & 97.1 & 2 \\
\hline \multirow{4}{*}{$\mathrm{CaCl} 2$} & 1000 & 2.26 & 88.6 & 6.67 & 3.9 & 91.6 & 1.1 \\
\hline & 2000 & 2.1 & 89.5 & 9.09 & 2.8 & 92 & 0.91 \\
\hline & 5000 & 3.4 & 91.3 & 0.33 & 6.2 & 91.5 & 1.36 \\
\hline & 10000 & 5.71 & 91 & 0.37 & 7.8 & 91 & 1.23 \\
\hline \multirow{4}{*}{ MgSO4 } & 1000 & 1.28 & 92.8 & 0.68 & 3 & 93.4 & 0.95 \\
\hline & 2000 & 1.88 & 92.6 & 0.64 & 2.3 & 93.3 & 1 \\
\hline & 5000 & 1.94 & 92.4 & 0.88 & 3.5 & 94.4 & 1.43 \\
\hline & 10000 & 4.93 & 95.1 & 4.88 & 7.9 & 96.1 & 1.08 \\
\hline
\end{tabular}

Table 3: Mass transfer coefficient, salt rejection and water flux for different salts at different concentrations.

This rejection behavior can be explained as: the membrane surface appeared to be positively charged with divalent salts and negatively charged in the presence of $\mathrm{NaCl}$ [25]. In case of $\mathrm{MgSO}_{4}, \mathrm{MgCl}_{2}, \mathrm{CaSO}_{4}$ and $\mathrm{Ca}\left(\mathrm{HCO}_{3}\right)_{2}$ salts, there is a strong adsorption of $\mathrm{Mg}^{2+}$ and $\mathrm{Ca}^{2+}$ ions yielding revere of the sign of the membrane charge so that the membrane becomes positively charged. This could explain the fact that those salts are better rejected than $\mathrm{NaCl}$ in case of natural feed water, where $\mathrm{Mg}^{2+}$ and $\mathrm{Ca}^{2+}$ are the co-ions (ion with the same sign of the charge as the membrane charge) and have a higher valence than chloride which is the co-ion in case of $\mathrm{NaCl}$. 


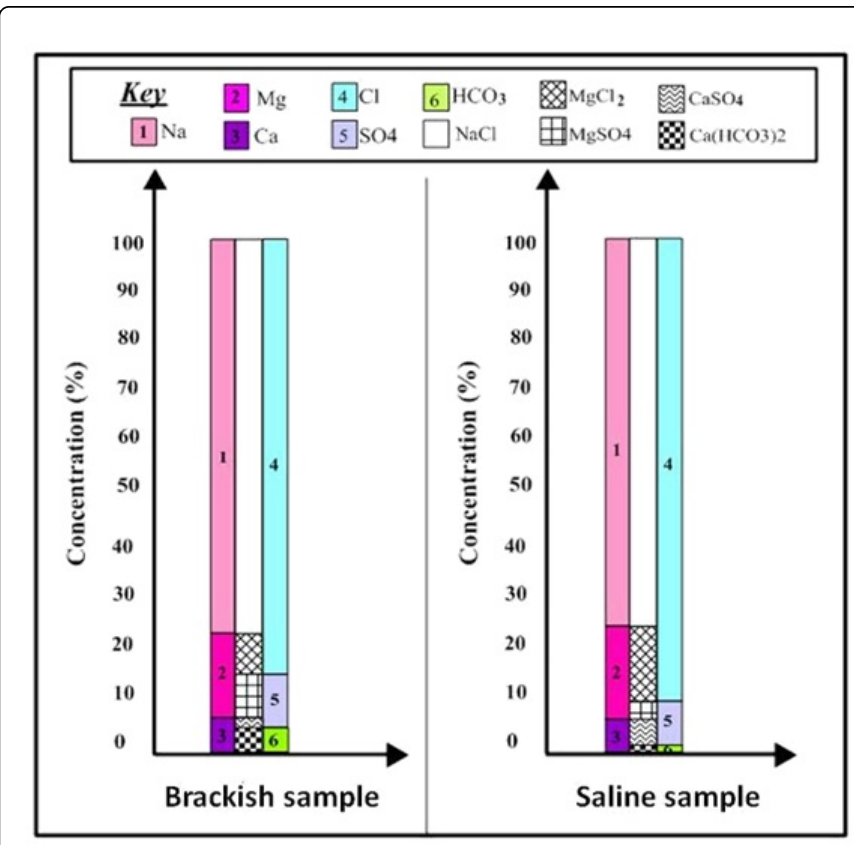

Figure 6: Bar graphs representing hypothetical salts of the brackish and saline groundwater samples.

These results suggest that each ion could have its individual contribution to the membrane charge by means of adsorption; this phenomenon is attributed to ionic adsorption at the interface membrane/solution. On the basis of Donnan exclusion theory, a high co-ion valence causes a higher salt rejection [26,27]. Also, a strong affinity of chloride ions for the membrane material (stronger than sulfate and bicarbonate ions) has been found, this affinity causes a lower positive charge for $\mathrm{MgCl}_{2}$ than $\mathrm{MgSO}_{4}$. In case of brackish groundwater sample, Figure $8 \mathrm{a}$, the sequence of cations rejection $\left(\mathrm{R}_{0}\right.$ \%) is: $\mathrm{R}_{\mathrm{o}} \mathrm{Mg}^{2+}>\mathrm{R}_{\mathrm{o}} \mathrm{Ca}^{2+}>\mathrm{Ro} \mathrm{Na}^{+}$, while the sequence of anions rejection is: $\mathrm{R}_{\mathrm{o}} \mathrm{SO}_{4}{ }^{2-}>\mathrm{R}_{\mathrm{o}} \mathrm{Cl}^{-}>\mathrm{R}_{\mathrm{O}} \mathrm{HCO}_{3}{ }^{-}$. Whereas the cations rejection sequence in the saline sample, Figure $8 \mathrm{~b}$ is in the order: $\mathrm{R}_{\mathrm{o}} \mathrm{Mg}^{2+}>\mathrm{R}_{\mathrm{o}}$ $\mathrm{Ca}^{2+}>\mathrm{Ro} \mathrm{Na}^{+}$and the anions rejection is in the order: $\mathrm{R}_{\mathrm{o}} \mathrm{SO}_{4}{ }^{2-}>\mathrm{R}_{\mathrm{o}}$ $\mathrm{HCO}_{3}{ }^{-}>\mathrm{R}_{\mathrm{o}} \mathrm{Cl}^{-}$. From these figures, it is obvious that the retention for the bivalent anions is lower than that of cations. Also, the retention of bivalent ions was higher than that of monovalent ones. This can be explained due to one of the three factors; the first is the ionic radii and hydrated ionic radii, where the ionic and hydrated ionic radii of divalent ions in solution are larger than that of monovalent ions, Table 2. The second is based on the different cationic valence rejection sequence which can be explained by the Donnan exclusion theory, which suggests that a higher valence co-ion causes a higher ion rejection, whereas a higher valence counter ion (neutral species) leads to a lower rejection of the salt. For the same valence ions, the rejection sequence could be affected by the difference in ion diffusivities, i.e., an ion is retained more if it has a smaller diffusivity, Table 2, this is inversely reflected in the rejection sequence [25]. Those factors can explain the high rejection of $\mathrm{Mg}^{2+}$ and $\mathrm{Ca}^{2+}$ counter-ions more than $\mathrm{Na}^{+}$. The third is based on the hydration energy, where the difference of retention can be attributed to the difference of energy hydration between the divalent and monovalent ions; the more hydrated the divalent ions, the more difficult their transfer across the membrane [28], Table 2. Consequently, $\mathrm{SO}_{4}{ }^{2-}$ and $\mathrm{HCO}^{3-}$ ions, which are more strongly hydrated than $\mathrm{Cl}^{-}$ions, become difficult to permeate through the membrane. So, the rejection of ions is written in the order: $\mathrm{R}_{0}$ $\mathrm{SO}_{4}^{2-}>\mathrm{R}_{\mathrm{o}} \mathrm{HCO}^{3-}>\mathrm{R}_{\mathrm{o}} \mathrm{Cl}^{-}$and $\mathrm{R}_{\mathrm{o}} \mathrm{Mg}^{2+}>\mathrm{R}_{\mathrm{o}} \mathrm{Ca}^{2+}>\mathrm{R}_{\mathrm{o}} \mathrm{Na}^{+}$.

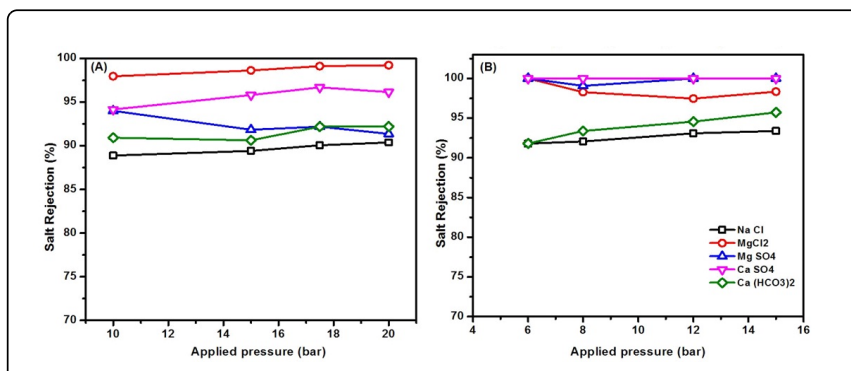

Figure 7: Rejection of hypothetical salts at different applied pressures of saline (A) and brackish (B) groundwater samples.

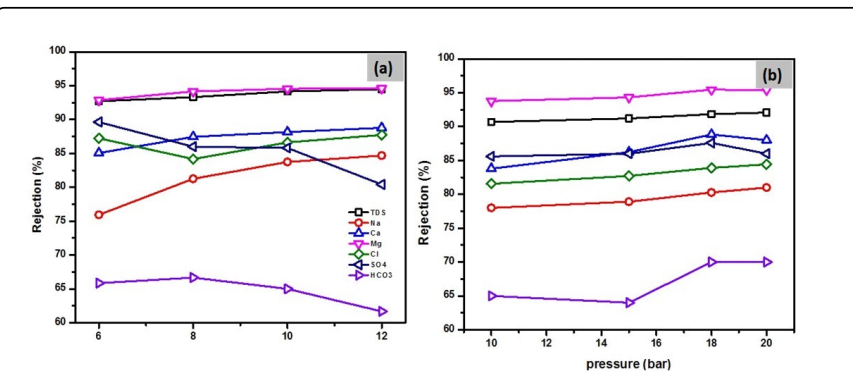

Figure 8: Rejection of TDS and different ions in groundwater samples at different applied pressures, (a) brackish sample and (b) saline sample. 
Citation: Gallab AAS, Ali MEA, Shawky HA, Abdel-Mottaleb MSA (2017) Effect of Different Salts on Mass Transfer Coefficient and Inorganic Fouling of TFC Membranes . J Membr Sci Technol 7: 175. doi:10.4172/2155-9589.1000175

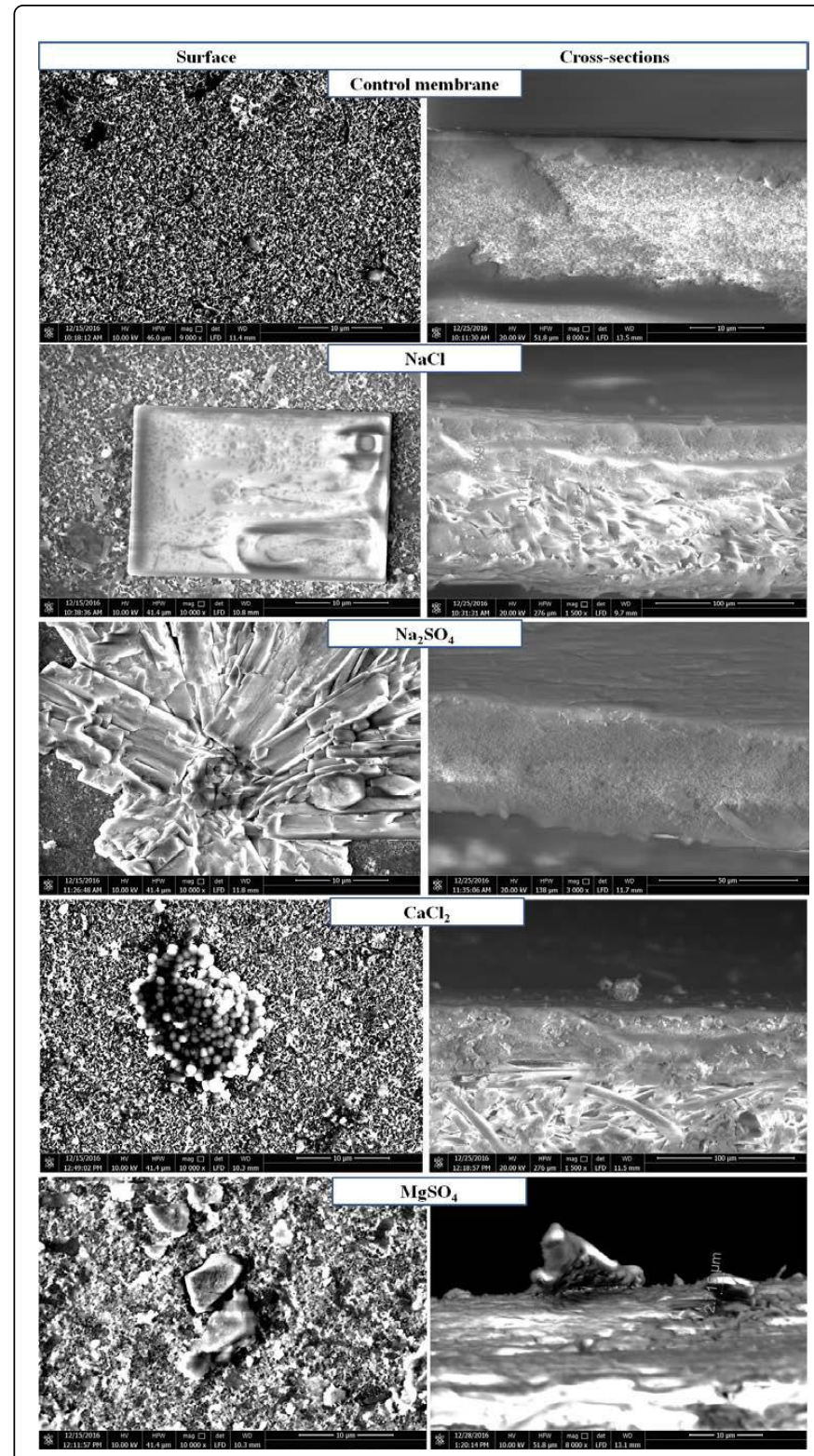

Figure 9: SEM images of surfaces (left) and cross- sections (right) of the membranes after desalination of synthetic solutions of different salts.

Table 4 shows the attitude of the ' $\mathrm{k}$ ' values as a function of changing the pressure and feed concentration with time of two groundwater samples. In case of the brackish groundwater sample, as the operation time increase, the feed concentration increase due to the brine mixing. Where, the salt rejection was observed to be increased with decreasing of $\mathrm{k}$ values with time decreased. This is may be due to the low concentration polarization formed, which render the membrane couldn't hinder the further salt passage at the increased applied pressure. In the desalination of the saline groundwater, the lowering of $\mathrm{k}$ values at the low pressure is due to an increased salt concentration with time.

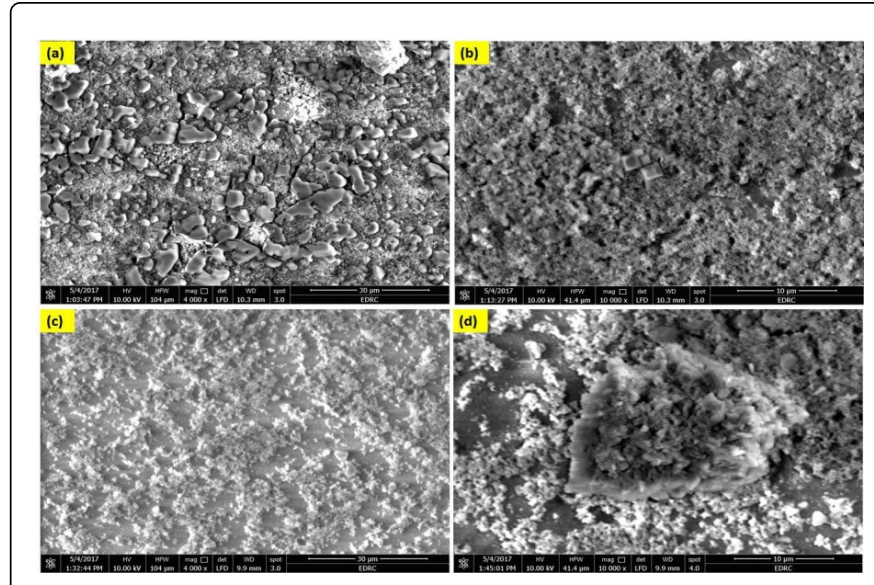

Figure 10: SEM images of the membranes after desalination of brackish $(\mathrm{a} \& \mathrm{~b})$ and saline $(\mathrm{c} \& \mathrm{~d})$ groundwater samples at two different magnifications of 4000 (left) and 1000 (right).

This reflects formation of a concentration polarization layer, which indicates the membrane deterioration. In fact, the $\mathrm{k}$ values continued to decrease with increasing the applied pressure as the concentration polarization continued to grow in thickness until it prevents more salt passage. It is clear that the ' $\mathrm{k}$ ' values for the groundwater desalination are higher than that of desalination of a single salt in the feed solution. This is because groundwater feed rich in mineral salts compared. From these results, it is concluded that the formation of CP layer, which is responsible for the ' $\mathrm{k}$ ' values trend, depend on the concentration of feed solution and the nature of sample. It is clear that the ' $\mathrm{k}$ ' values for the groundwater desalination are higher than that of desalination of a single salt in the feed solution. This is because groundwater feed rich in mineral salts.

\begin{tabular}{|c|c|c|c|c|c|}
\hline \multicolumn{6}{|c|}{ Brackish sample } \\
\hline Salinity & \multirow{2}{*}{\multicolumn{2}{|c|}{$\begin{array}{l}\text { Applied } \\
\text { Pressure } \\
\text { (bar) }\end{array}$}} & \multirow{2}{*}{ Salt Rejection (\%) } & Water flux & \multirow{2}{*}{$\mathrm{k}(\mathrm{m} / \mathrm{s}) \times 10^{-2}$} \\
\hline$(\mathrm{mg} / \mathrm{l})(\mathrm{m} / \mathrm{s}) \times 10^{-2}$ & & & & $J_{v}\left(L / m^{2} \cdot h r\right)$ & \\
\hline 5380 & $\begin{array}{l}P=2 \\
\pi\end{array}$ & 8 & 92 & 16.7 & 10.4 \\
\hline 5440 & & & 92.93 & 11.9 & 8.1 \\
\hline 5300 & $\begin{array}{l}\mathrm{P}=3 \\
\pi\end{array}$ & 12 & 92.4 & 17 & 5.9 \\
\hline 5460 & & & 95.2 & 21.2 & 8.2 \\
\hline \multicolumn{6}{|c|}{ Saline sample } \\
\hline 8540 & $\begin{array}{l}\mathrm{P}=2 \\
\pi\end{array}$ & 9.5 & 92 & 8.3 & 4 \\
\hline 10090 & & & 91 & 7.86 & 10 \\
\hline 10200 & $\begin{array}{l}P=3 \\
\pi\end{array}$ & 14 & 92 & 9.5 & 8 \\
\hline 10600 & & & 91 & 13.3 & 6 \\
\hline
\end{tabular}

Table 4: Mass transer coefficient values in the desalination of ground feed water. 
Page 8 of 9

Figure 8 shows SEM images of the flat sheet membrane for $\mathrm{NaCl}$ $\mathrm{Na}_{2} \mathrm{SO}_{4}, \mathrm{CaCl}_{2}$ and $\mathrm{MgSO}_{4}$ salts at constant concentration of 5000 $\mathrm{mg} / \mathrm{l}$ in order to examine the salts accumulation on the membrane surface. Each membrane was allowed to completely dry at room temperature before scanning its surface. In case of $\mathrm{NaCl}$ and $\mathrm{Na}_{2} \mathrm{SO}_{4}$ as feed solutes, SEM images show formation of uniform crystals shape, respectively, onto the membrane surface without any crystalline formation inside the active layer as shown from the cross-section image. Therefore, the inorganic fouling due to these salts could be external fouling which is a reversible and can be easily washed away by rinsing with dilute acid solution. SEM images of $\mathrm{CaCl}_{2}$ as feed solution show precipitation of the salt as twinned-bread and random shape crystals $[29,30]$. In addition, the crystalline formation of the salt inside the active layer, cross-section image, indicates the internal fouling, which is a probability of irreversible membrane fouling that deteriorates the membrane performance. The coral-reef-like and random shape crystals was observed in case of using $\mathrm{MgSO}_{4}$ as feed solution with scales distribution inside the polyamide active layer. This effect agreed with the obtained experimental $\mathrm{RO}$ results in which the water flux obtained from calcium and magnesium salts were less that the permeated water flux obtained from the sodium salts. The deteriorating effect of magnesium and calcium salts is attributed to their lower solubility product than sodium salts.

Figure 9 shows SEM images of the membrane after desalination of actual two brackish groundwater samples with salinity of 5380 and $8540 \mathrm{mg} / \mathrm{l}$. Where a higher degree of fouling and more developed crystal shapes was observed in addition its propagation as a function of salinity increases. It could be conclude that SEM images of the membrane surface after desalination of groundwater samples indicates that the cause of formed fouling is mainly due to precipitation of calcium and magnesium salts due to their low solubility product. This is because when the feed solution contains more than one salt, redissolution of sparingly soluble salts with highest solubility product would happen to preserve equilibrium at membrane surface interface.

\section{Conclusion}

Salt intrinsic properties such as the hydrated ion radius and the diffusivity of ions contribute in the salt transport behavior through the TFC RO membranes. The solute transport parameters such as the mass transfer coefficient ' $\mathrm{k}$ ' was found to be highly affected by the change in the operation conditions such as the feed solute concentration and the cross flow applied pressure. They were also different from one salt to another. From the results, the larger cations with higher diffusivity were found to cause a problem to the membrane owing to the high CP effect, while the smaller cations with relatively low diffusivity lead to lower formation of CP layer. SEM images also confirmed the very high degree of fouling caused by calcium and magnesium salts. It was found that, the membrane fouling in case of sodium salts was an external fouling (reversible) only and can be easily eliminated using a rinse solution containing very dilute acid. While Calcium \& Magnesium salts cause internal \&external fouling (irreversible) and cause permanent damage to the membrane. According to cross-flow results, it was found that calcium and magnesium salts fouled the membrane more than sodium salts, and the salt rejection percentage were in the order of $\mathrm{Na}_{2} \mathrm{SO}_{4}>\mathrm{NaCl}>\mathrm{MgSO}_{4}>\mathrm{CaCl}_{2}$ in case of synthetic solutions and $\mathrm{CaSO}_{4}>\mathrm{MgSO}_{4}>\mathrm{MgCl}_{2}>\mathrm{Ca}\left(\mathrm{HCO}_{3}\right)_{2}>\mathrm{NaCl}$ in case of groundwater desalination.

\section{References}

1. Khawaji AD, Kutubkhanah IK, Wie JM (2008) Advances in seawater desalination technologies. Desalination 221: 47-69.

2. Lin SW, Pérez Sicairos S, Félix Navarro RM (2007) Preparation, characterization and salt rejection of negatively charged polyamide nanofiltration membranes. Journal of the Mexican Chemical Society 51: 129-135.

3. Zhang L, Xu J, Tang Y, Hou J, Yu L, et al. (2016) A novel long-lasting antifouling membrane modified with bifunctional capsaicin-mimic moieties via in situ polymerization for efficient water purification. Journal of Materials Chemistry 4: 10352-10362.

4. She Q, Wang R, Fane AG, Tang CY (2016) Membrane fouling in osmotically driven membrane processes: a review. Journal of Membrane Science 499: 201-233.

5. Zhou W, Song L, Guan TK (2006) A numerical study on concentration polarization and system performance of spiral wound RO membrane modules. Journal of Membrane Science 271: 38-46.

6. Sutzkover I, Hasson D, Semiat X (2000) Simple technique for measuring the concentration polarization level in a reverse osmosis system. Desalination 131: 117-127.

7. Zaidi SJ, Fadhillah F, Khan Z, Ismail A (2015) Salt and water transport in reverse osmosis thin film composite seawater desalination membranes. Desalination 368: 202-213.

8. Goosen MF, Sablani SS, Al-Maskari SS, Al-Belushi RH, Wilf M (2002) Effect of feed temperature on permeate flux and mass transfer coefficient in spiral-wound reverse osmosis systems. Desalination 144: 367-372.

9. Al-Bastaki NM, Abbas A (2000) Predicting the performance of RO membranes. Desalination 132: 181-187.

10. Taniguchi M, Kurihara M, Kimura S (2001) Behavior of a reverse osmosis plant adopting a brine conversion two-stage process and its computer simulation. Journal of Membrane Science 183: 249-257.

11. Sundaramoorthy S, Srinivasan G, Murthy D (2011) An analytical model for spiral wound reverse osmosis membrane modules: Part I-Model development and parameter estimation. Desalination 280: 403-411.

12. Geise GM, Paul DR, Freeman BD (2014) Fundamental water and salt transport properties of polymeric materials. Progress in Polymer Science 39: 1-42.

13. Song L, Hong S, Hu J, Ong S, Ng W (2002) Simulations of full-scale reverse osmosis membrane process. Journal of environmental engineering 128: 960-966.

14. Prabhakar S, Ramani MPS (1994) A new concept of mass transfer coefficient in reverse osmosis-practical applications. Journal of Membrane Science 86: 145-154.

15. Jonsson G, Boesen C (1977) Concentration polarization in a reverse osmosis test cell. Desalination 21: 1-10.

16. Wijmans J, Baker R (1995) The solution-diffusion model: a review. Journal of Membrane Science 107: 1-21.

17. Murthy Z, Gupta SK(1999) Sodium cyanide separation and parameter estimation for reverse osmosis thin film composite polyamide membrane. Journal of Membrane Science 154: 89-103.

18. Gill WN, Matsumoto MR, Gill AL, Lee YT (1988) Flow patterns in radial flow hollow fiber reverse osmosis systems. Desalination 68: 11-28.

19. Košutić K, Dolar D, Kunst B (2006) On experimental parameters characterizing the reverse osmosis and nanofiltration membranes' active layer. Journal of Membrane Science 282: 109-114.

20. Nightingale Jr E (1959) Phenomenological theory of ion solvation. Effective radii of hydrated ions. The Journal of Physical Chemistry 63: 1381-1387.

21. Kang KC, Linga P, Park KN, Choi SJ, Lee JD (2014) Seawater desalination by gas hydrate process and removal characteristics of dissolved ions $(\mathrm{Na}+$, $\mathrm{K}+, \mathrm{Mg} 2+$, Ca 2+, B 3+, Cl-, SO 4 2-). Desalination 353: 84-90.

22. Volkov A, Paula S, Deamer D (1997) Two mechanisms of permeation of small neutral molecules and hydrated ions across phospholipid bilayers. Bioelectrochemistry and Bioenergetics 42: 153-160. 
Citation: Gallab AAS, Ali MEA, Shawky HA, Abdel-Mottaleb MSA (2017) Effect of Different Salts on Mass Transfer Coefficient and Inorganic Fouling of TFC Membranes . J Membr Sci Technol 7: 175. doi:10.4172/2155-9589.1000175

Page 9 of 9

23. Esfahani IJ, Kim M,Yun C, Yoo C (2013) Proposed new fouling monitoring indices for seawater reverse osmosis to determine the membrane cleaning interval. Journal of Membrane Science 442: 83-96.

24. Collins (1923) Graphic Representation of Water Analyses. Industrial \& Engineering Chemistry 15: 394-394.

25. Schaep J, Vandecasteele V, Mohammad AW, Bowen WR (2001) Modelling the retention of ionic components for different nanofiltration membranes. Separation and purification Technology 22: 169-179.

26. Seidel A, Waypa JJ, Elimelech M (2001) Role of charge (Donnan) exclusion in removal of arsenic from water by a negatively charged porous nanofiltration membrane. Environmental Engineering Science 18: 105-113.
27. Schaep J, Van der Bruggen B, Vandecasteele V, Wilms D (1998) Influence of ion size and charge in nanofiltration. Separation and purification Technology 14: 155-162.

28. Antropo L (1975) Electrochimie théorique Mir. New York 5: 362.

29. Guo L, Liu W, Wang J, Zhang Y, Wang SH, Yu (2011) Controlled crystallization of hierarchical and porous calcium carbonate crystals using polypeptide type block copolymer as crystal growth modifier in a mixed solution. CrystEngComm 13: 2054-2061.

30. Gorna G, Hund KM,Vučak M, Gröhn F, Wegner (2008) Amorphous calcium carbonate in form of spherical nanosized particles and its application as fillers for polymers. Materials Science and Engineering 477: 217-225. 